(c) Group of authors, 2019

UDC 616.717.3:021.2

DOI - https://doi.org/10.14300/mnnc.2019.14131

ISSN - 2073-8137

\title{
IMMUNOHISTOPATHOLOGICAL CHANGES OF BONE TISSUE DURING CHRONIC GENERALIZED PERIODONTITIS
}

\author{
Sirak S. V. 1, Shchetinin E. V. 1, Garunov M. M. ${ }^{2}$, Grigoryants L. A. ${ }^{2}$, \\ Andreev A. A. ' , Petrosyan G. G. ', Dzgoeva M. G. ${ }^{3}$ \\ 1 Stavropol State Medical University, Russian Federation \\ 2 Peoples' Friendship University of Russia, Moscow, Russian Federation \\ ${ }^{3}$ North Ossetian State Medical Academy, Vladikavkas, Russian Federation

\section{ИММУНОГИСТОМОРФОАОГИЧЕСКИЙ АНААИЗ ИЗМЕНЕНИЙ КОСТНОЙ ТКАНИ ПРИ ХРОНИЧЕСКОМ ГЕНЕРААИЗОВАННОМ ПАРОАОНТИТЕ}

\author{
С. В. Сирак ${ }^{1}$, Е. В. Шетинин ${ }^{1}$, М. М. Гарунов ${ }^{2}$, А. А. Григорьянц ${ }^{2}$, \\ А. А. Анареев ${ }^{1}$, Г. Г. Петросян ${ }^{1}$, М. Г. Азгоева ${ }^{3}$
}
${ }^{1}$ Ставропольский госуаарственный меАицинский университет, Российская ФеАерация
2 Российский университет Аружбы нароАов, Москва, Российская ФеАерация
${ }^{3}$ Северо-Осетинская госуАарственная меАицинская акаАемия, ВлаАикавказ, Российская Фелерация

The morphology of osteonecrotic processes and osteogenesis of experimental periodontitis with various degrees of severity were examined in 60 white outbred rats. In bone tissue of the alveolar process during chronic generalized periodontitis, immunohistomorphology revealed resorption processes with the participation of macrophages in the form of swelling and total lysis of osteocytes and histiocytes. Disruption of osteogenesis with insufficient bone neoplasm was noted during the progression of the disease, when along with intensive osteolytic processes, atypical bone formation was observed. Furthermore, in some areas of the bone tissue of the alveolar process, there was an inordinate change in resorption and bone-building processes. Therefore, a description of the pathological process in the form of «bone atrophy» does not reflect the pathology, whereas «osteoporosis and bone tissue repair» most accurately explains the mechanisms and manifestations of the pathological process of chronic generalized periodontitis.

Keywords: periodontitis, bone, alveolar process, osteoporosis

На 60 белых беспородных крысах исследована морфология остеонекротических процессов и процессов остеогенеза при экспериментальном пародонтите различной степени тяжести. В костной ткани альвеолярного отростка при хроническом генерализованном пародонтите иммуногистоморфологически выявлены резорбционные процессы с участием макрофагов в виде набухания и тотального лизиса остеоцитов и гистиоцитов. Нарушение остеогенеза с недостаточным новообразованием кости отмечено при прогрессировании заболевания, когда наряду с интенсивными остеолитическими процессами наблюдается атипичное костеобразование, а в отдельных участках костной ткани альвеолярного отростка - беспорядочная смена процессов рассасывания и построения кости. Термин «атрофия кости» не отражает сути, в то время как «остеопороз и рарефикация костной ткани» наиболее точно объясняют механизмы и проявления патологического процесса при хроническом генерализованном пародонтите.

Ключевые слова: пародонтит, кость, альвеолярный отросток, остеопороз

For citation: Sirak S. V., Shchetinin E. V., Garunov M. M., Grigoryants L. A., Andreev A. A., Petrosyan G. G., Dzgoeva M. G. IMMUNOHISTOPATHOLOGICAL CHANGES OF BONE TISSUE DURING CHRONIC GENERALIZED PERIODONTITIS. Medical News of North Caucasus. 2019;14(3):532-535. DOI - https://doi.org/10.14300/mnnc.2019.14131

Для цитирования: Сирак С. В., Щетинин Е. В., Гарунов М. М., Григорьянц Л. А., Андреев А. А., Петросян Г. Г., ДЗГОеВа М. Г. ИММУНОГИСТОМОРФОЛОГИЧЕСКИЙ АНАЛИЗ ИЗМЕНЕНИЙ КОСТНОЙ ТКАНИ ПРИ ХРОНИЧЕСКОМ ГЕНЕРАЛИЗОВАННОМ ПАРОДОНТИТЕ. Медицинский вестник Северного Кавказа. 2019;14(3):532-535. DOI - https://doi.org/10.14300/mnnc.2019.14131

EMA - epithelial membrane antigen

IHC - immunohistochemistry

NSE - neuron-specific enolase
V9 - vimentin

$\alpha$-SMA - $\alpha$-smooth muscle actin 
C hronic generalized periodontitis is an inflammatory dystrophic disease leading to tooth loss as often as complications of caries $[1,2]$. Depending on the severity of periodontitis, morphological changes in the bone tissue of the alveolar bone of the jaw become more pronounced. They are especially pronounced in severe cases of the disease $[3,4]$.

The clinical and radiological indicators are very clear, and the issue is not diagnosis of periodontitis, but the degree of destruction in bone tissue of the alveolar process [5, 6]. Moreover, the metabolic changes occurring in the jaw bone remain controversial in addition to the legitimacy of the use of the terms «osteoporosis» and «bone atrophy» for chronic generalized periodontitis $[4,7,8]$.

The aim of the study was to evaluate pathological changes in the bone tissue of the alveolar bone of the jaw during chronic generalized periodontitis by immunohistomorphology.

Material and Methods. This study used 60 white outbred male rats weighing 180-200 g. Periodontal tissues of 10 normal rats were used for comparison.

To establish an experimental model of periodontitis, oral dysbiosis was induced by intramuscular injection of lincomycin hydrochloride at a dose of $30 \mathrm{mg} / 100 \mathrm{~g}$ body weight, according to a previously published method [9]. Local lesions of the gums and tissues of the vestibule in the mouth were established by application of a suspension of bee venom at a dose of $2-5 \mathrm{mg} / 100 \mathrm{~g}$ body weight. Applications were performed in two sections of the vestibule of the mouth between the lower lip and incisors of the lower jaw and between the molars of upper and lower jaws and the cheek on the right. Animals were housed in a common cage with an area of $0.015 \mathrm{~m}^{2}$ per individual. During the experiment (30 days), $4 \mathrm{ml}$ sunflower oil per animal was added to the standard diet, which was heated in the presence of $2 \%$ copper sulfate for 24 hours until the peroxide value was above 20-40 U.

Depending on the severity of periodontal lesions to be modeled, the dose of the bee venom was changed from 2 to $5 \mathrm{mg}$ per $100 \mathrm{~g}$ body weight $(2,3$, and $5 \mathrm{mg}=$ mild, moderate, and severe periodontitis, respectively). In addition, peroxide in sunflower oil was increased $(20,30$, and 40 $\mathrm{U}=$ mild, moderate, and severe periodontitis, respectively).

When modeling severe periodontitis in rats, a scheme similar to that described above with additional intramuscular administration of ammonium chloride at a dose of $5 \mathrm{mg} / 100 \mathrm{~g}$ body weight once a day for 7 days was used.

The experimental model of chronic generalized periodontitis was considered to be established by the following clinical and radiological signs: periodontal pockets of $5 \mathrm{~mm}$ or deeper, gingival hyperemia and bleeding, cortical plate discontinuity along the edge of the dental alveoli, and alveolar atrophy.

Animals were sacrificed by an overdose of ether on days $7,14,21$, and 60 after establishment of the periodontitis model. Biopsy specimens of interdental bone septa and bone tissue of the alveolar ridge from the lateral parts of the upper and lower jaws were obtained.

After fixation in $10 \%$ neutral formalin for 7 days, the isolated tissues were decalcified in $12 \%$ nitric acid and then placed in celloidin. Sections were stained with hematoxylin-eosin or subjected to picrofuxin by van Gieson staining, and Mallory and Masson staining.

For immunohistochemistry (IHC), we used monoclonal murine antibodies against vimentin (V9), $\alpha$-smooth muscle actin ( $\alpha$-SMA, 1A4), neuron-specific enolase (NSE), and epithelial membrane antigen (EMA, E29)
(SpringBioScience, USA). The immunohistochemical reactions were performed on paraffin-embedded sections using the highly sensitive imaging system Revealbiotin-freepolyvalent DAB (SpringBioScience). IHC staining was imaged under an Olympus BX45 digital microscope. For morphometry, we used the Video-TestMorphology 5.1 program for Windows.

All surgical interventions were performed under general anesthesia (Zoletil 50) in compliance with established requirements.

Data were processed by variation statistics according to Fischer-Student in Primer of Biostatistics 4.03 for Windows. Differences were considered significant at $\mathrm{p}<0.05$.

Results and Discussion. Signs of gingival inflammation corresponding to mild periodontitis in the experimental rats were observed on day 7. By day 14, swelling and cyanosis of the gums were distinct, periodontal pockets appeared in the incisor area up to $2 \mathrm{~mm}$ deep, and incisor mobility was $2-3^{\circ}$, corresponding to periodontitis of moderate severity. On day 21 , all signs of destruction of the top of the interdental septum were determined radiologically, including lysis of the latter, $3^{\circ}$ tooth mobility, and periodontal pockets of more than $5 \mathrm{~mm}$ deep, corresponding to severe periodontitis.

Morphological analysis also confirms the effectiveness of the method to establish a model of chronic periodontitis in rats, which excluded periodontal surgical injury.

On day 7 after the establishment of experimental periodontitis, IHC showed significant changes in cellular components of bone tissue and the side of the intercellular substance. In cells of neuroectodermal origin, intense expression of coarse-grained cytoplasmic immunoreactive material was noted. Cells positive for NSE (an isoform of the enolase necessary for glycolysis) were located mainly near blood vessels (Fig. 1a). Less commonly, NSE+ cells were seen in the area of the bone substance in osteons of intact trabeculae and periosteum (Fig. 1b). Bone cells of the alveolar ridge underwent dystrophic changes during the process of oncosis and were then destroyed. The metabolism and structure of the intercellular bone substance were also disrupted.

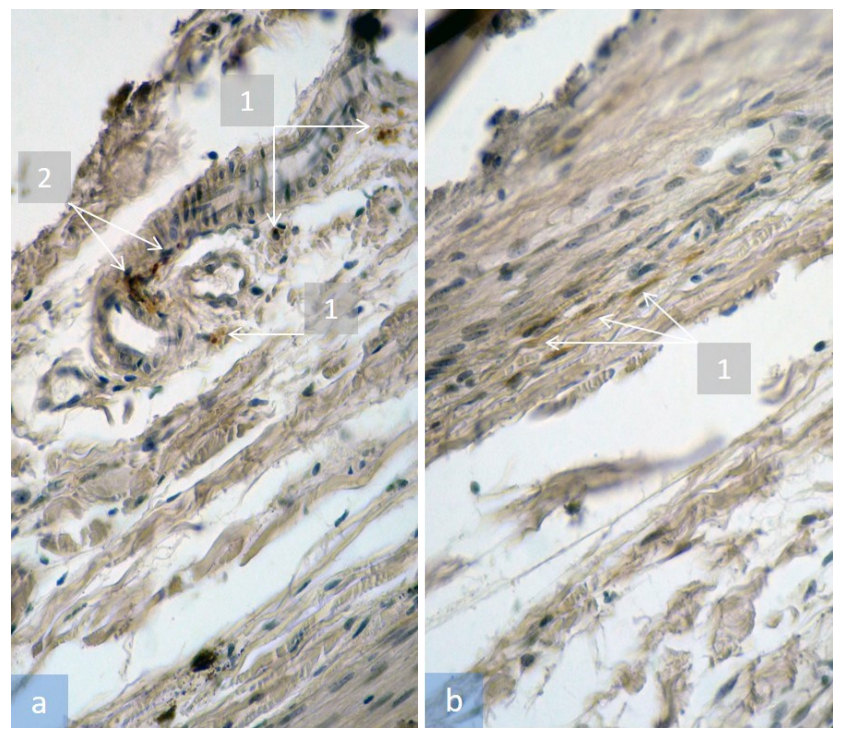

Fig. 1. Micrograph of a biopsy fragment from the dentoalveolar segment of the lateral lower jaw on day 7 (chronic generalized periodontitis of mild severity): a - NSE+ cells around blood vessels (1) and NSE+ cells in the wall of arterioles (2). IHC of NSE. Positive staining is brown. Ok. 10, Obj. 400;

$\mathrm{b}-\mathrm{NSE}+$ cells in the periosteum (1). IHC of NSE. Positive staining is brown. Ok. 10, Obj. 400 
By day 14 , the foci of destruction of the alveolar bone in the area of osteocyte oncosis did not tend to increase. The destruction process consisted mainly of leaching calcium from the bone matrix and homogenization of bone tissue, but not the formation of lacunae in the bone substance (Fig. 2a). In some areas, the destruction of the alveolar process in the oncosis zone preceded cell death, and in areas of complete osteocyte lysis, it was so pronounced that hematopoietic loosening of connective tissue necrosis, osteonecrosis of the bone tissue sections with gradual exposure, and decay of the collagen base of the bone were observed (Fig. 2b). As a result, lacunae formed in the bone tissue and the alveolar bone was rectified.
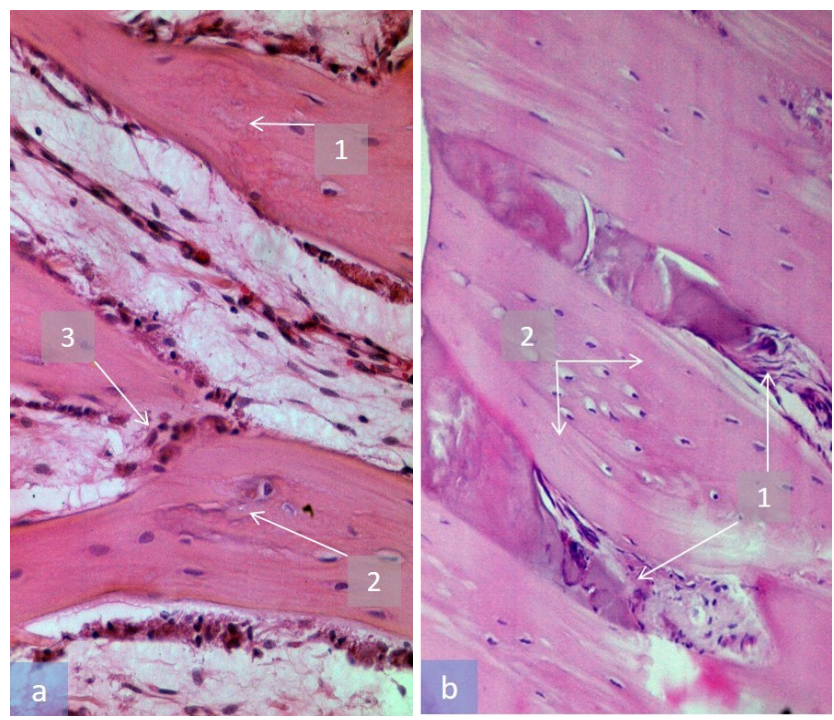

Fig. 2. Microphotographs of a biopsy fragment from the dentoalveolar segment of the lateral lower jaw on day

14 (chronic generalized periodontitis of moderate severity):

a-Zones of calcium leaching from the bone matrix (1),

cementing lines for bonding bone fragments (2), and

osteoblasts (3); b - Necrosis of hematopoietic loosening

of connective tissue (1) and osteonecrosis of bone tissue (2). Hematoxylin and eosin staining. Ok. 10, Obj. 40

Dystrophy of bone tissue with restructuring characterized by a decrease in the number of bone trabeculae per unit volume of the alveolar bone during periodontitis was greatly facilitated by the proliferation of cells such as macrophages, which was especially pronounced and observed in all areas at this stage of the disease. Resorption by macrophages proceeded from both the side of the edges of bone structures (from the side of the endosteum and periosteum) and in the compact and perimedullar layer. In addition to osteocyte lysis, they were modified and converted into the most aggressive cellular element (i.e., macrophages). These occurrences indicated particularly deep disruption of the bone tissue in the alveoli of the tooth.

Resorption with the assistance of histiocytes in the compact and perimedullar layer often occurred towards resorption from the endosteum and periosteum. In the walls of the formed cavities, resorption of the bone continued, both with the participation of histiocytes, and smooth, segmental resorption with the appearance of sites of dissimilation due to the activation of epithelioid cells and osteoclasts.

The occurrence of osteonecrosis was associated with significant acceleration of osteolysis in certain areas of the bone with complete simultaneous dissolution of all constituents of the bone substance (osteocytes, collagen fibers, and amorphous adhesive and mineral salts). The rapid development of the osteolytic process led to a plasma-like homogeneous bone mass at the site of bone tissue, without any microscopically visible stages of its formation.

$\mathrm{IHC}$ to detect polysaccharides revealed accumulation of acid mucopolysaccharides in bone tissue in the area of destruction zones. Bone metachromasia was completely removed by incubation of the sections in a hyaluronidase solution. This phenomenon is the result of enzyme cleavage of acid mucopolysaccharides formed during bone resorption. In addition, acid mucopolysaccharides were intensively stained by hematoxylin and eosin, and the revealed basophilia of tissues was due to the acidic properties of the stained cellular components, mainly nucleic acids.

On day 21 of severe periodontitis, the processes of bone tissue resorption of the alveolar process occurred in all areas. In some areas, the processes of resorption and bone building had changed dramatically. Active EMA+ cells were found in the intertrabecular cavities of the damaged area of the cortical plate (Fig. 3a).

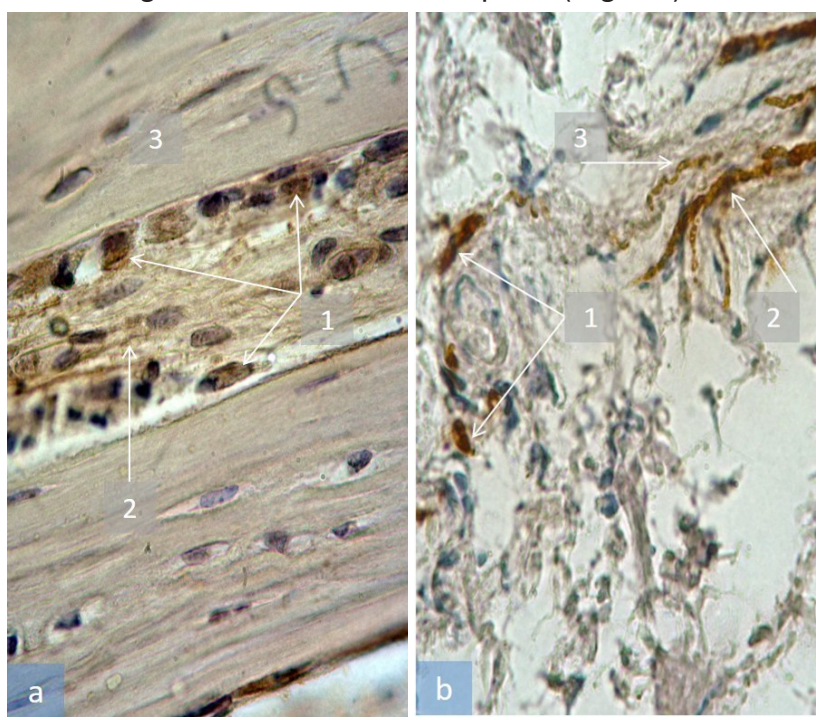

Fig. 3. Microphotographs of a biopsy fragment from the dentoalveolar segment of the lateral lower jaw on days 21 (a) and 60 (b) (severe generalized periodontitis): a - Active EMA+ cells (1) in the intertrabecular cavities (2) of the damaged part of the bone plate (3). IHC of EMA. The reaction product is brown. Ok. 10, Obj. 100; b - Active synaptophysin+ cells with nerve terminals (1) and total destruction of the nerve synapse

(2) with terminals (3). IHC of synaptophysin. The reaction product is brown. Ok. 10, Obj. 400

By day 60 , bone neoplasm slowed or stopped, because the newly formed bone substance was immediately subjected to lysis with total destruction of nerve synapses and terminals (Fig. 3b). The newly formed bone tissue had a loose, coarse beam structure and differed from intact bone in pronounced basophilia. In some areas, bone substance with an amorphous structure was found, which was completely calcified with a small amount of the main gluing substance. The bone formed by the osteoblasts had low strength indicated by the numerous microcracks and fractures.

Thus, the bone tissue of the alveolar bone with severe periodontitis had a rather mottled histological picture. Because of the intense osteolysis in combination with an atypical structure, boneless sections of the bone, friable, blocky-granular foci, basophilic bone areas, homogenous foci with an erased pattern of the structure, lacunae, cracks, and microfractures appeared.

These pathomorphological signs of bone atrophy in the jaw alveolar bone with chronic generalized periodon- 
titis revealed its anatomical and physiological nature and indicated the pathological processes occurring in bone materials, which were similar to those in modeling osteoporosis or destruction of bone tissue by chronic stress $[10,11]$.

Conclusions. During chronic generalized periodontitis, the main types of bone tissue resorption of the alveolar process are oncosis, as a form of cell death in which there is no activation of the genetically determined mechanism of cellular self-destruction, and conversely, resorption processes involving macrophages in the form of swelling and total lysis of osteocytes and histiocytes. Destructive changes in bone tissue were clearly observed in addition to the endosteum and periosteum in both the compact and perimedullar sections of the thinned compact plate of the alveolar ridge of the jaw without the formation of hypervascularization zones characteristic of any loaded bone tissue.

In the bone tissue of the alveolar process of the jaw, chronic generalized periodontitis occurs in phases. In the early phase of the pathological process (periodontitis of mild severity, i.e., day 7 of the study), many types of bone resorption with active participation of tissue-specific glycolytic enzymes were most clearly seen. With the progression of disease along with intensive osteolytic processes, atypical bone formation was observed (periodontitis of moderate severity, i.e., day 14 of the study), and in some parts of the bone tissue of the alveolar bone, a random change in the processes of bone resorption and construction (severe periodontitis, i.e., day 21 of the study) occurred.

Therefore, the use of the term «bone atrophy» for chronic generalized periodontitis does not reflect the ongoing metabolic changes, whereas the use of the term «bone osteoporosis» for periodontitis most accurately indicates the pathological process and the term «ratification» describes its dynamics.

Financing. The study was carried out within the framework of the State Task of the Ministry of Health of the Russian Federation for Research and Development on the topic «Directional regeneration of periodontal tissues in experimental osteoporosis».

Informed consent: The experiments were carried out in accordance with the international principles of the European Convention on the Protection of Vertebrate Animals used for Experiments and Other Scientific Purposes (Strasbourg, 1986), in the principles of good laboratory practice (National Standard «Principles of Good Laboratory Practice» GOST R 53434-2009), international recommendations on conducting biomedical research using animals (1985), the Laboratory Practice Rules in the Russian Federation (Order of the Ministry of Health of the Russian Federation, № 267 on 19.06.2003), and «General ethical principles of animal experiments» (Russia, 2011), and approval of the ethics committee.

\section{Disclosures:}

The authors declare no conflict of interest.

\section{Acknowledgment:}

We thank M. Arico from Edanz Group (www.edanzediting.com/ac) for editing a draft of this manuscript.

\section{References}

1. Galiullina E. F. Novye podhody k jetiologii zabolevanij parodonta v svete sovremennoj koncepcii ih patogeneza (obzor literatury). Parodontologija. - Periodontology. 2017;(2):2124.

2. Emecen-Huja P., Li H.-F., Ebersole J. L., Lambert J., Bush H. Epidemiologic evaluation of Nhanes for environmental Factors and periodontal disease. Scientific Reports. 2019;9(1):8227. https://doi.org/10.1038/s41598-019-44445-3

3. Koshukova G. N., Pushkova T. N., Babushkina N. S. Zajaeva A. A. Osobennosti klinicheskih projavlenij, diagnostiki i lechenija osteoporoza $\vee$ praktike vrachastomatologa. Tavricheskij mediko-biologicheskij vestnik. Tauride Medical-Biological Herald. 2016;(3):158-167.

4. Mau L. P., Kuan Y. C., Tsai Y. C., Lin J. J., Huynh-Ba G. [et al.] Patients with chronic periodontitis present increased risk for osteoporosis: a population-based cohort study in Taiwan. Journal of Periodontal Research. 2017;52(5):922929. https://doi.org/10.1111/jre.12464

5. Orehova L. Yu., Chibisova M. A., Serova N. V. Kliniko-luchevaja harakteristika hronicheskogo generalizovannogo parodontita. Parodontologija. - Periodontology. 2013;(3):3-9.

6. Arzhancev A. P. K voprosu o rentgenodiagnostike okolokornevyh vospalitel'nyh destruktivnyh processov v cheljustjah. Stomatologija dlja vseh. - Dentistry for all. 2018;(2):24-29.
7. Zhu S., Ehnert S., Rouß M., Häussling V., AsperaWerz R. H. [et al.] From the clinical problem to the basic research-co-culture models of osteoblasts and osteoclasts. International Journal of Molecular Sciences. 2018;19(8):E2284. https://doi.org/10.3390/ijms19082284

8. Bykova N. I., Sirak S. V., Sepiashvili R. I., Ovsyannikova $A$. A. The pathogenetic substantiation of therapy for the chronic generalized periodontitis in patients suffering from the glucocorticoid osteoporosis. International Journal on Immunorehabilitation. 2018;20(1):40-43.

9. Sirak S. V., Shchetinin E. V., Bykova N. I., Vafiadi M. Yu., Petrosyan G. G., Didenko N. N. A method of obtaining an experimental model of periodontitis. Patent RUS 2676649, 09.10.2017.

10. Tsygan V. N., Shulenin K. S., Koskin S. A., Kovalevsky A. M., Borodulina I. I. [et al.] Drug induced patomorphosis in parodont and environmental bone tissue in experimental use of corticosteroids. Medical News of North Caucasus. 2018;13:529-533. https://doi.org/10.14300/ mnnc.2018.13097

11. Petrosyan G. G., Sirak S. V., Romanenko R. G., Tarabrina A. G., Shchetinin E. V. Stress-indutsirovannyye narusheniya struktury tkaney parodonta $v$ eksperimente na zhivotnykh. Meditsinskii vestnik Severnogo Kavkaza. - Medical News of North Caucasus. 2018:13:73-77. https://doi.org/10.14300/mnnc.2018.13021

\section{About authors:}

Sirak Sergey Vladimirovich, MD, PhD, Professor, Head of the Department of dentistry;

tel.: +78652350551; e-mail: sergejsirak@yandex.ru; http://orcid.org/0000-0002-4924-5792

Shchetinin Evgeny Vyacheslavovich, MD, PhD, Professor, Head of the Department of pathophysiology;

tel.: +78652352524; e-mail: ev.cliph@rambler.ru; http://orcid.org/0000-0001-6193-8746

Garunov Musa Magomedovich, Senior Laboratory Assistant of the Department of dentistry; tel.: +78652350551; e-mail: leondent@mail.ru

Grigoryants Leon Andronikovich, MD, PhD, Professor, Head of the Department of dentistry; tel.: +79857843120; e-mail: leondent@mail.ru

Andreev Anton Aleksandrovich, postgraduate student; tel.: +78652350551; e-mail: kafedra@mail.ru

Petrosyan Grigorii Grigorievich, MD, Associate Professor of the Department of pathophysiology;

tel.: +78652352684; e-mail: patphysiology@stgmu.ru

Dzgoeva Madina Georgievna, MD, PhD, Head of the Departament of dentistry № 1; tel.: +78672280375 